\title{
Screen Time dalam Perilaku Pengasuhan Gererasi Alpha pada Masa Tanggap Darurat Covid-19
}

\author{
Hardiyanti Pratiwi ${ }^{凶}$ \\ Pendidikan Islam Anak Usia Dini, Universitas Islam Negeri Antasari Banjarmasin \\ DOI: $10.31004 /$ obsesi.v5i1.544
}

\begin{abstract}
Abstrak
Tujuan penelitian ini untuk mengenahui peningkatan intensitas akses perangkat digital oleh anak selama WFH, bagaimana polanya, apa saja factor yang mempengaruhinya, dan apa dampaknya terhadap aspek perkembangan anak. Penelitian ini menggunakan metode kualitatif-naratif untuk menceritakan perilaku screen time dalam pengasuhan anak usia dini di masa tanggap darurat Covid-19. Screen time adalah waktu yang dihabiskan anak di depan layar, baik smartphone, televisi, laptop, tab atau media digital lainnya. Analisis data menggunakan teknik Miles Hubermen yang terdiri dari tiga tahap, yaitu reduksi, penyajian dan verifikasi data. Hasil penelitian menunjukkan bahwa ada 6 faktor yang mempengaruhi pola, intensitas dan jangka waktu anak usia dini dalam menggunakan perangkat digital. Peningkatan intensitas terjadi apabila orang tua belum menerapkan disiplin dalam penggunaan perangkat digital oleh anak, minimnya ide permainan dan teman sebaya. Tujuan mengakses perangkat digital untuk hiburan. Perangkat digital dapat meningkatkan aspek kognitif namun berdampak negatif pada aspek sosial emosional.
\end{abstract}

Kata Kunci: screen time; pengasuhan; generasi alpha; work and study from home

\begin{abstract}
The purpose of this study was to find out the increase in intensity of access to digital devices by children during WFH, how their patterns, what factors influenced them, and what their impact on aspects of child development. This study uses a qualitative-narrative method to describe screen time behavior in early childhood care in the Covid-19 emergency response period. Screen time is the time children spend in front of the screen, whether smartphone, television, laptop, tab, or other digital media. Data analysis using the Miles Hubermen technique which consists of three stages, namely reduction, presentation, and verification of data. The results showed that 6 factors influenced the pattern, intensity, and duration of early childhood use of digital devices. Increased intensity occurs when parents have not implemented discipline in the use of digital devices by children, the lack of game ideas and peers. The purpose of accessing digital devices is for entertainment. Digital devices can improve cognitive aspects but have a negative impact on social-emotional aspects.
\end{abstract}

Keywords: screen time; nurturing; alpha generation; work and study from home

Copyright (c) 2019 Hardiyanti Pratiwi

$\square$ Corresponding author :

Email Address : diyankonayuki@gmail.com (Banjarmasin, Indonesia)

Received 20 May 2020, Accepted 4 June 2020, Published 7 June 2020 


\section{PENDAHULUAN}

Presiden Joko Widodo, melalui konferensi pers di istana Bogor hari Minggu, tanggal 15 Maret 2020 menginstruksikan kebijakan untuk beraktivitas dari rumah dalam rangka menekan laju penyebaran virus covid19. Kebijakan tersebut utamanya terkait pada aktivitas belajar, bekerja dan beribadah (nasional.kompas.com, 2020). Pidato kepresidenan ini ditanggapi menteri pendidikan dan kebudayaan, Nadiem Makarim dengan menyatakan dukungan kepada pemerintah daerah untuk meliburkan sekolah karena mempertimbangkan keselamatan dan keamanan peserta didik atas penyebaran virus ini. Dukungan kementerian pendidikan dan kebudayaan ini kemudian dituangkan dalam Surat Edaran Nomor 4 Tahun 2020 tentang Pelaksanaan Kebijakan Pendidikan dalam Masa Darurat Penyebaran Coronavirus Disease (pusdiklat.kemdikbud.go.id, 2020)

Kebijakan ini juga diimplementasikan pada jenjang pendidikan anak usia dini. Dengan diliburkannya PAUD, maka orang tua diharapkan dapat mengambil alih peran yang selama ini dijalankan oleh guru. Orang tua memiliki porsi peran yang lebih besar dalam membantu anak mereka belajar. Selain itu, mereka juga memegang kendali mengawal serta memberikan stimulus untuk proses perkembangannya, mulai dari aspek kognitif, agama dan moral, sosial emosional, bahasa, seni hingga fisik dan motoriknya.

Interaksi orang tua dan anak adalah faktor terpenting dalam pengembangan diri anak jangka panjang secara keseluruhan. Secara bersamaan, penggunaan layar oleh orang tua dan anak, mengurangi waktu yang dihabiskan bersama. Karena itu, kehadiran perangkat digital menjadi tantangan baru dalam pengasuhan. Namun perangkat digital malah menjadi solusi andalan orang tua ketika mereka merasakan kejenuhan dalam menghadapi tingkah laku anak. Dengan memberikan perangkat digital kepada anak, mereka menjadi lebih tenang dan mudah dikontrol. Dalam sebuah surveinya, (V. J. Rideout, 2013) melaporkan sekitar $44 \%$ orang tua mengatakan mereka "sering" atau "kadang" mengizinkan anak-anak mereka untuk menggunakan perangkat digital sementara mereka menjalankan tugas. Survei lain menemukan bahwa intensitas interaksi anak-anak terhadap media berkorelasi sedang dengan kebutuhan orang tua untuk menyelesaikan tugas (Cingel \& Krcmar, 2013).

Dari persepsi kebanyakan anak usia dini, perangkat digital memainkan peran penting dalam kehidupan sehari-hari mereka, baik untuk bermain video game, menggunakan aplikasi, atau streaming Video YouTube. Para peneliti telah lama berpendapat bahwa bagaimana anak-anak menghabiskan waktu mereka memiliki pengaruh substansial dalam perkembangan keterampilan, hubungan, sikap, dan pola perilaku mereka (Huston, Wright, Marquis, \& Green, 1999).

Selain alasan di atas, pijakan orang tua dalam memberikan perangkat digital kepada anak adalah agar mereka dapat menyesuaikan diri dengan perkembangan zaman sejak dini dan sebagai media bermain sekaligus belajar. Banyak orang tua, pendidik, dan peneliti menyadari bahwa cara anak-anak belajar sedang berubah. Perangkat digital dapat memberikan peluang belajar yang sangat canggih bagi anak usia dini. Perangkat digital sangat interaktif dan mudah untuk dioperasikan oleh anak-anak dengan keterampilan motorik mereka yang terbatas (Chiong \& Shuler, 2010).

Anak usia dini sekarang dipenuhi peluang untuk belajar dengan gaya abad 21, di mana teknologi meresap dalam keseharian mereka. Anak usia dini dapat belajar secara informal, hanya dengan ditemani perangkat digital. Maka tidak mengherankan ketika (CommonSenseMedia, 2013) merilis laporan bahwa paling sedikit anak usia di bawah 8 tahun dapat menghabiskan 2 jam penuh di depan layar. Seiring produksi massal smartphone dengan harga yang murah, orang tua tidak segan membelikan perangkat tersebut khusus untuk anaknya. Hanya dalam 2 tahun antara 2011 dan 2013, penggunaan perangkat seluler meroket: penggunaan oleh anak dengan umur di bawah 2 tahun meningkat dari $10 \%$ menjadi 38\%, sedangkan penggunaan oleh anak-anak berusia 2-4 tahun meningkat 39\% hingga $80 \%$ (Cristia \& Seidl, 2015). Bahkan dalam riset di USA yang dilakukan oleh (V. J. 
Rideout, 2013) dan dikuatkan juga oleh hasil riset (Cristia \& Seidl, 2015) di Prancis diketahui setidaknya $20 \%$ bayi diasuh dengan bantuan perangkat digital setiap harinya.

Dasar keterampilan kognitif yang dipelajari selama masa usia dini memiliki dampak besar terhadap kesuksesan skolastik masa depan. Apalagi karakter perangkat digital dengan berbagai program dan aplikasinya sangat cocok dengan karakter anak usia dini sehingga dapat membentuk ikatan afektif yang kuat di antara mereka. Dalam domain perkembangan anak usia dini, media digital mungkin dapat mempromosikan percepatan proses belajar anak, khususnya aspek bahasa dan STEM (Science, Technology, Engineering, and Mathematics).

Dampak negatif perangkat digital terhadap aspek perkembangan anak diketahui ketika dihadapkan dengan sebuah pertanyaan; seberapa positif kecepatan perkembangan bahasa dan kognitif mereka itu jika diletakkan dalam situasi ketika mereka harus berinteraksi dengan alam nyata? Akar masalah ini adalah bahwa media dengan kecanduan yang diakibatkannya, membatasi anak dari dunia nyata di mana mereka dapat memperoleh pelajaran dari pengalaman berinteraksi secara sosial, dengan sebaya maupun alam. Adalah sebuah fakta bahwa perangkat digital tidak menyediakan bahkan menyekat interaksi sosial. Peningkatan screen time dikaitkan dengan obesitas pada anak, penurunan kebugaran, attention deficits, dan skor kesehatan psikososial yang rendah (LeBlanc et al., 2012; Tremblay et al., 2011)

Perangkat digital dapat memiliki pengaruh langsung pada anak-anak. Konten yang dimuat dalam perangkat digital memiliki dua mata sekaligus. Ia dapat memberikan informasi juga disinformasi. Tidak kalah penting, perangkat ini juga dapat menginduksi perilaku antisosial. Selain itu, perangkat digital juga memiliki efek tidak langsung dalam mempengaruhi hubungan antara orang tua dengan anaknya. Kualitas interaksi sosial antara orang tua dan anak-anak adalah faktor penting dalam perkembangan kognitif, bahasa, dan sosial.

Dengan ditetapkannya work and study from home, tentu orang tua dan anak memiliki banyak waktu untuk dihabiskan bersama. Namun apakah situasi ini dapat mereduksi screen time pada pengasuhan anak atau malah intensitasnya semakin meningkat. Inilah distingsi penelitian ini dengan penelitian terdahulu. Selain itu, penelitian ini juga bertujuan mengungkap faktor-faktor yang mempengaruhi intensitas screen time anak dan alasan yang mendasari keputusan orang tua untuk mengizinkan anak mengakses perangkat digital. Data-data dari penelitian ini dapat membantu orang tua untuk mengelola screen time bagi anaknya, memaksimalkan nilai-nilai positif dan mereduksi nilai-nilai negatif dari perangkat digital dan menghindari adiksi perangkat digital sejak dini.

\section{METODOLOGI}

Metode yang digunakan dalam penelitian ini adalah metode kualitatif dengan jenis penelitian naratif. Responden merupakan orang tua yang berdomisili di Kota Banjarmasin dan melaksanakan kebijakan bekerja dari rumah. Data dikumpulkan sejak dikeluarkannya surat edaran Kemendikbud tanggal 24 Maret 2020 hingga 14 Mei 2020. Peneliti mengumpulkan data dari responden melalui rekaman audio, video dan dokumentasi via whatsapp dan zoom.

Langkah yang ditempuh peneliti dalam melaksanakan penelitian naratif ini adalah sebagai berikut: 


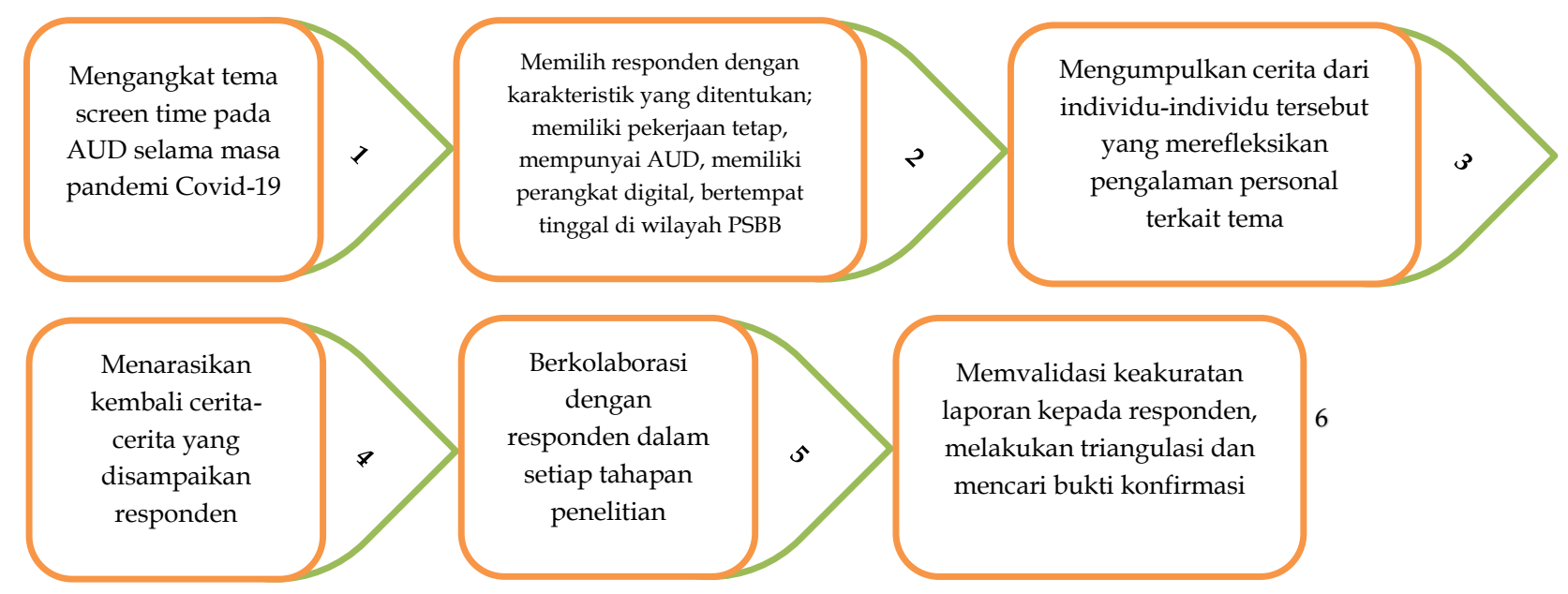

\section{Gambar 1 Langkah penelitian naratif}

Ada 7 keluarga yang berpartisipasi sebagai sumber data dalam penelitian naratif ini. Seluruh keluarga tersebut memenuhi ciri-ciri spesifik yang ditentukan untuk merangkum cerita tentang paparan media dalam pola pengasuhan anak di masa tanggap darurat penyebaran virus Covid-19. Responden dari 7 keluarga tersebut terbagi dalam 4 karakter; keluarga dengan 1 anak tanpa ada bantuan pengasuhan, keluarga dengan anak sibling, keluarga yang anaknya menderita speech delay dan single parent. Seluruh responden merupakan generasi millenial, yaitu mereka yang lahir pada tahun 80 an. Mereka memiliki anak yang dikategorikan sebagai generasi alpha, yang lahir setelah tahun 2010. Generasi millennial, yang merasakan transisi antara analog ke digital, memiliki tantangan tertentu dalam membesarkan generasi alpha. Anak-anak ini memiliki tingkat resiliensi yang rendah, interaksi sosial yang terbatas dan karenanya, nilai juga norma sosial mereka berbeda dengan generasi sebelumnya.

Responden pertama Ibu D (R1) berasal dari keluarga yang beranggotakan tiga orang, ayah, ibu dan seorang anak. Responden menjalani long distance marriage dengan suaminya karena sang suami menjadi PNS di luar kota. Anak laki-laki mereka, Al (3 tahun 6 bulan) diasuh oleh sang Ibu dan dibawa setiap sang Ibu mengajar di kota Banjarmasin. Ketika ibunya mengajar, biasanya Al bermain bersama para mahasiswi atau anak-anak dosen lainnya. Jika tidak seorangpun yang menemani $\mathrm{Al}$, ibunya akan membawa $\mathrm{Al}$ ke ruang laboratorium PIAUD. Namun apabila Al masih bosan, maka ibunya akan meminjamkan smartphone kepadanya.

Responden kedua Ibu At (R2) memiliki anggota keluarga empat orang. Responden ini juga menjalani LDM dengan suaminya. Responden diangkat menjadi guru PNS di luar kota. Kedua anaknya yang sibling, Um ( 6 tahun 1 bulan) dan Wld (4 tahun 11 bulan) dibawa serta oleh sang Ibu dan tinggal di rumah mertua. Mereka bersekolah TK dan KB di kota tersebut. Sedangkan sang ayah bekerja sebagai PNS di kota Banjarmasin dan menjenguk mereka ke rumah nenek seminggu sekali.

Responden ketiga Ibu H (R3) tinggal di rumah bersama suami, Ibu dan 3 orang anaknya yang sibling. Ia dan suaminya sama-sama bekerja sebagai dosen di universitas berbeda di kota Banjarmasin. Anak mereka, Aj ( 5 tahun 5 bulan), At (4 tahun 2 bulan), dan Ay (1 tahun 2 bulan) diasuh oleh neneknya.

Responden keempat Ibu M (R4) baru memutuskan untuk berpisah dengan suaminya karena orang tua suami terlalu dalam masuk ke wilayah privat keluarganya. Anak mereka, Alf ( 4 tahun 5 bulan) secara bergantian tinggal di rumahnya selama 4 hari dan di rumah mantan suaminya 3 hari. Perbedaan pola asuh yang dia terapkan dan yang berlaku di rumah suaminya menjadi isu yang menurutnya harus selalu dicarikan solusi. 
Responden kelima Ibu S (R5) masih tinggal di rumah orang tuanya bersama suami dan anaknya. Rumah tersebut dihuni 6 anggota keluarga yang semuanya mempunyai kesibukan sendiri sehingga responden dan anaknya Az (3 tahun 4 bulan) hanya tinggal berdua, terkadang bertiga dengan neneknya di rumah. Seperti khasnya perumahan elit, keluarga ini jarang berinteraksi dengan tetangga karena kesibukan mereka yang sama-sama padat.

Responden keenam Ibu K (R6) tinggal dalam sebuah rumah bersama keluarga besarnya. Ada 5 orang dewasa dan 5 orang anak yang tinggal di rumah tersebut. Walaupun sudah berpisah dan menjadi single parent sejak 2 tahun lalu, R6 merasa tidak kewalahan dalam mengasuh anak karena banyaknya sepupu yang dapat menemani anaknya.

Responden ketujuh Bapak L (R7) merupakan keluarga baru yang memiliki 1 orang anak laki-laki Rf ( 2 tahun 4 bulan). Responden merupakan pegawai kontrak di sebuah puskesmas dan istrinya PNS di rumah sakit umum daerah. Sang istri mengatur jadwal shift kerja agar tidak berbarengan dengan suaminya. Sebelum Covid-19 menyebar di Indonesia, Rf bersekolah di KB tak jauh dari rumahnya.

\section{HASIL DAN PEMBAHASAN}

\section{Intensitas Screen Time, Jangka Waktu dan Pola Penggunaannya}

Ibu D (R1) menuturkan bahwa tidak banyak perubahan intensitas penggunaan perangkat digital pada anaknya, baik sebelum dan ketika belajar dari rumah. "Malah sepertinya lebih sering ketika sebelum covid", ujarnya. Ibu D menceritakan bahwa sebelum WFH, intensitas screen time anaknya sangat fluktuatif. Setiap Ibu D memiliki kesibukan dan tidak ada orang yang menemani anaknya bermain, maka ia akan meminjamkan smartphone kepada anak.

Adapun ketika ditanya mengenai intensitas interaksi anak dengan perangkat digital saat belajar dari rumah, Ibu D menjawab, "Kalau saat covid ini, kan ada ayahnya yang menemani ketika saya ngajar online. Begitu juga kalau jadwal ayahnya ngajar, saya yang menemani anak." Ketika ditanya lebih jauh, Ibu D menuturkan bahwa ia sudah menetapkan disiplin sejak sebelum covid yang mengatur agar anaknya hanya menggunakan HP maksimal 3 kali dalam sehari. Pagi sekitar pukul 10, siang sebelum tidur siang atau sore setelahnya dan terkadang malam. Jangka waktu penggunaannya pun tetap, yaitu sepuluh menit. "saya sudah membuat janji bersama dengan anak dan ini menjadi kebiasaan", ujar Ibu D, "bahwa kalau ia mau main HP, harus dikasih alarm 10 menit. Kalau alarm berbunyi, anak biasanya langsung menyerahkan HP tersebut."

Berbeda dengan pengalaman Ibu D, Ibu At (R2) mengakui bahwa ia sangat ketat membatasi interaksi anaknya dengan smartphone, baik sebelum WSFH maupun ketika WSFH. "Kecuali hanya untuk foto bareng, misalnya." Ibu At menyatakan bahwa anaknya tidak pernah lagi meminta untuk meminjam smartphone. Hal ini berawal ketika anaknya pernah mengalami ledakan emosi (tantrum) karena tidak diperbolehkan untuk memakai smartphone, yang kemudian ditanggapi dengan pelarangan smartphone untuk anak. Namun jika ada smartphone diletakkan di sembarang tempat, tidak dikunci, biasanya anak-anak Ibu At langsung memakainya untuk menonton youtube. "Tapi kami sudah terbiasa mematikan akses data jika selesai menggunakan smartphone," jelasnya.

Jika anak terlanjur menggunakan smartphone karena orang tua meletakkan di sembarang tempat, lupa mengunci dan mematikan paket data, maka biasanya Ibu At membiarkan anaknya terlebih dahulu mempergunakan smartphone tersebut. "Nanti kalau dirasa waktunya sudah cukup lama, saya ambil smarphonenya. Pinjam dulu. Lalu saya matikan akses datanya." Anak hanya menunjukkan kekecewaan verbal jika tidak bisa mengakses youtube lagi. Mereka hanya tahu, keadaan seperti itu berarti pulsa habis.

Karena akses untuk smartphone ditutup, kedua anak Ibu At akhirnya lebih banyak menghabiskan waktu di depan televisi. "Karena anak-anak full diam di rumah aja, intensitas dan jangka waktu nontonnya lebih banyak dibanding sebelum WSFH. Paling biasanya dimatikan satu jam, habis itu dinyalain lagi. Ditinggal main sebentar, nonton lagi. Jika kakak nonton, adiknya juga 
pasti nonton," papar Ibu At. Ibu At menyatakan bahwa ia mengizinkan anaknya mengakses perangkat digital, terutama televisi karena anak tidak memiliki kegiatan lain yang menyenangkan bagi mereka. Anak-anak Ibu At pernah tantrum jika dilarang menonton televisi, karena itu keluarga Ibu At menghindari kata melarang. Mereka lebih memilih untuk menyiasati dengan menghilangkan sinyal atau mencabut kabel televisi tanpa diketahui anak.

Di rumah Ibu At, hampir seluruh aktivitas dilakukan di ruang keluarga. Mereka menonton televisi, makan, istirahat, tidur-tiduran, mengaji dan WFH di situ. Dengan kondisi seperti ini, orang tua dapat memantau program televisi yang ditonton anak. "Kita bisa tungguin mereka sampai selesai nonton, sambil dijelaskan. Terutama kartun yang ada aksi perkelahiannya."

Adapun menurut penuturan Ibu $\mathrm{H}$ (R3), kedua anaknya tidak mengalami peningkatan yang besar dalam hal mengakses perangkat digital saat WSFH. Ibu H sudah menanamkan kebiasaan kepada anak bahwa mereka hanya mengakses laptop atau HP ketika bersama ibunya saja. "Saya memang menganggap bahwa menggunakan HP sudah bagian dari keseharian anak. Biasanya mereka menghabiskan waktu 1-2 jam sekali nonton. Antara 3-4 kali sehari."

Pengalaman berbeda diceritakan oleh Ibu M (R4). Ia dan suaminya berpisah sejak beberapa bulan yang lalu. Pengasuhan anak mereka, Alf dilakukan berjadwal. Dalam satu minggu, Alf diasuh oleh ayahnya selama 3 hari dan oleh ibunya selama 4 hari. Ibu M menuturkan bahwa anaknya tidak mengalami pengingkatan akses terhadap perangkat digital. "Kalau di rumah saya, biasa-biasa saja seperti sebelum Covid," ujar Ibu M. Namun Ibu M mengkhawatirkan pola asuh yang diterapkan oleh ayah dan neneknya. "Di sana Alf punya HP sendiri. Ayahnya beli Hp baru. Mereka sangat bebas dalam mempergunakan HP, mungkin karena terlalu sayang dengan cucu." Untuk mencegah kemungkinan munculnya sikap reaktansi dari anak karena perbedaan pola asuh ini, Ibu M mengunduh video-video yang menjelaskan dampak negatif karena akses smartphone berlebih. "Kalau ia mau pinjam HP saya, saya kasih video itu. Jadinya ia gak berani lama-lama pegang HP." Terangnya.

Ibu M juga terkejut karena dalam beberapa bulan ini, keahlian anaknya dalam mennggunakan smartphone dan pengetahuannya tentang berbagai aplikasi sangat meningkat drastis. Sekarang Alf sudah tahu cara mencari video di youtube, pandai menggunakan WA, instagram dan facebook. Karena pengalaman interaksi anak dengan smartphone ini sudah beragam, Ibu M tidak dapat menerapkan disiplin yang tegas dalam mengatur penggunaan smartphone. "Disiasati aja agar dia mengakses yang bermanfaat. Saya unduh aplikasi marbel, mengenal huruf hijaiyah, bentuk dan lainnya. Selain itu juga sering saya alihkan untuk bermain dengan sepupunya. Kalau di rumah abahnya, tidak ada teman." Ibu M menyatakan bahwa alasannya meminjamkan smartphone untuk anak adalah agar anaknya tidak menggangu ketika ia bekerja. Selain itu, Ibu M juga meminjamkan anaknya smartphone untuk belajar melalui berbagai aplikasi yang sudah diunduhnya.

Ibu S (R5) juga menceritakan bahwa ada perubahan intensitas dan jangka waktu yang dihabiskan anaknya untuk mengakses perangkat digital saat pandemi covid-19 ini. Jadwal harian anaknya sebelum SFH adalah sekolah dari pagi hingga pukul 11.00. Setelah pulang sekolah, biasanya anak tidur hingga waktu makan siang. Anaknya selalu makan, baik pagi siang dan malam sambil menonton youtube. Setelah makan siang terkadang anaknya bermain, terkadang juga mengakses perangkat digital hingga sore. Namun sekarang, hampir setiap waktu kosong dan anaknya merasa bosan, ia akan mengakses perangkat digital, seringnya smartphone dan televisi. "Yang sering di rumah cuma saya, terkadang Ibu saya. Jadi anak kayaknya sering bosan. Jarang juga sih keluar komplek main sama teman-teman." Anak Ibu S tergolong mahir mempergunakan smartphone. Ia bahkan sudah bisa mengunduh game di playstore.

Karena Ibu $S$ adalah Ibu rumah tangga, ia sering menemani anaknya saat menonton video. "Kalau ia nonton saya ajak tanya jawab. Itu angka berapa, ini huruf apa?" ujarnya menirukan. Ibu S mengakui, ketika anak menggunakan smartphone atau menonton televisi, ia berusaha mengalihkan dengan bermain puzzle. "Anak saya suka puzzle. Tapi kalau dia sudah 
hapal puzzlenya, ia juga bosan sih." Alasan Ibu S mengizinkan anaknya mengakses perangkat digital adalah untuk menenangkan dia kalau lagi bosan dan rewel. Selain itu, jika Ibu S sibuk, ia juga sering meminjamkan smartphone kepada anaknya. Ibu S tidak ada menerapkan disiplin yang khusus mengatur penggunaan perangkat digital oleh anak. "Saya pun bebas saja memakai HP di depan anak, tidak perlu sembunyi-sembunyi. Anak juga kelihatannya biasa saja," jelas Ibu S.

Responden lainnya, Ibu K (R6) menyatakan bahwa sebelum WSFH anaknya tergolong sering mengakses smartphone. Bahkan Ibu K sempat ingin membelikan smartphone khusus untuk anaknya. Namun ketika WSFH, intensitas akses perangkat digital oleh anaknya malah berkurang. "Kan saya banyak di rumah. Kalau saya masak, baru saya kasih HP." Namun Ibu $\mathrm{K}$ tidak menerapkan disiplin apapun yang mengatur anak dalam mengakses perangkat digital. "Kalau ia bosan, baru ia main HP atau nonton Tv. Untungnya banyak sepupu yang menemani." Selain berprofesi sebagai guru honorer, Ibu K juga menjalankan bisnis online, karena itu ia sering menggunakan smartphone di depan anak. Ibu K juga sering meletakkan smartphonenya sembarangan. Namun Ibu K menjelaskan bahwa anaknya cukup koperatif. Kalau tidak diberi izin, ia tidak akan memakai smartphone.

Sedangkan Bapak L (R7) menyatakan bahwa intensitas akses perangkat digital oleh anaknya selama WSFH ini jauh meningkat. Sebelum WSFH, pagi hari hingga pukul 11 biasanya anaknya bersekolah di KB. Sepulang sekolah, anaknya tidur atau bermain sebentar dengan tetangga. Namun ketika WSFH, seluruh kegiatan ini diganti dengan menonton video di youtube atau menonton televisi. Anaknya juga cukup sulit untuk makan, kecuali jika dibarengi dengan menonton video. Bapak L mengakui bahwa ia cukup ketat membatasi kegiatan anaknya selama WSFH. "Mungkin karena saya bergelut di bidang kesehatan, jadi seperti memiliki kekhawatiran berlebih akan covid-19 ini," tegasnya.

Menurut Bapak L, selama WSFH ini istrinya bekerja pada shift siang sedangkan dirinya bekerja di pagi hari. "Jadi kalau pagi, anak sama istri di rumah. Nanti siang saya yang jaga anak," ujarnya. Melalui pengamatan peneliti, walaupun Bapak L tidak mempunyai kesibukan saat mengasuh anak, ia tergolong sering meminjamkan smartphone kepada anaknya. Rf hanya bermain jika ada teman sebaya yang datang ke rumahnya. Ketika dikonfirmasi mengenai hal ini, Bapak L beralasan bahwa ia lebih memilih anaknya bermain smartphone di rumah daripada bermain di luar rumah.

Data-data di atas menunjukkan bahwa mayoritas responden mengakui terjadi peningkatan intensitas dan jangka waktu screen time pada anaknya. Kegiatan bersekolah dan bermain bersama teman sebaya yang biasanya dilakukan anak sebelum penyebaran Covid19 berganti menjadi menonton televisi, video youtube atau bermain game di smartphone. Mayoritas responden juga mengakui bahwa mereka tidak menetapkan jadwal khusus bagi anak untuk menggunakan perangkat digital selama masa pandemi ini. Adapun jangka waktu yang dihabiskan anak untuk screen time sangat beragam tergantung strategi pembatasan yang dilakukan orang tua. Ada responden yang menyatakan anaknya mengakses smartphone antara 6-8 jam sehari. Ada pula yang mengungkapkan hampir di setiap waktu ketika anak bosan bermain sendiri, maka ia akan merengek untuk meminjam smartphone. Selain itu, ada juga responden yang menyatakan bahwa anaknya selalu membiarkan televise menyala walaupun ia tidak fokus menontonnya. Namun ada juga responden yang menyatakan bahwa selama WFH, malah intensitas screen time anaknya berkurang karena ada suami yang menemani anaknya bermain.

Orang tua, yang sebelum masa penyebaran Covid-19, disibukkan dengan jadwal padat dan hanya memiliki sedikit waktu untuk berinteraksi dengan anaknya, sekarang memiliki waktu yang banyak untuk dihabiskan bersama anak. Perubahan keseharian ini tentunya memerlukan proses adaptasi yang cepat. Belum lagi banyaknya faktor stress yang timbul seperti memburuknya kondisi keuangan, peningkatan kecemasan hingga kebosanan karena aktivitas yang dibatasi sekitar rumah membuat orang tua cenderung menyerahkan tanggung jawab pengasuhan anaknya kepada sebuah gawai. 
Dukungan pengasuhan ternyata dapat mereduksi intensitas screen time anak. Selain itu, disiplin yang ditetapkan dalam mengatur screen time juga berdampak besar dalam menjaga agar anak tidak mengakses perangkat digital berlebihan. Menurut salah satu responden, disiplin ini harus terus menerus diingatkan kepada anak dengan menjalin komuikasi dua arah yang baik.

Dari data-data yang telah dipaparkan di atas, setidaknya ditemukan ada 6 faktor yang mempengaruhi pola, intensitas dan jangka waktu anak usia dini dalam menggunakan perangkat digital, yaitu jumlah kesibukan orang tua, perilaku penggunaan perangkat digital oleh orang tua, jumlah saudara, pengetahuan orang tua tentang dampak penggunaan perangkat digital, kondisi lingkungan tempat anak tumbuh, dan dukungan pengasuhan dari pihak lain.

Seluruh responden menyatakan bahwa mereka merasa semakin sibuk ketika WFH. Walaupun pekerjaan kantor dapat dikerjakan di rumah dengan pengaturan waktu yang bebas, namun mereka juga harus menyelesaikan pekerjaan rumah tangga, mengasuh anak, bahkan harus membantu anak mengerjakan tugas sekolah. Semakin sibuk orang tua tanpa dukungan pengasuhan dari pihak lain, maka semakin sering kemungkinan anak mengakses perangkat digital. Perilaku penggunaan perangkat digital oleh orang tua juga memberikan pengaruh besar. Selama menjalankan work from home, orang tua lebih banyak menggunakan smartphone sebagai media kerja. Semakin sering anak melihat orang tuanya menggunakan perangkat digital dengan bebas, maka anak semakin sering menuntut untuk meminjam perangkat digital. Anak merupakan makhluk imitatif. Mereka meniru apa yang sering dilihatnya. Hal ini juga berlaku pada penggunaan perangkat digital oleh saudara dan kebiasaan akses perangkat digital di mana anak tumbuh, baik dari teman-teman maupun tetangga. Karena itu, orang tua perlu mengkondisikan lingkungan tempat anaknya tumbuh.

Peningkatan intensitas dan jangka waktu penggunaan perangkat digital pada masa pandemi covid-19 ini terjadi apabila orang tua dari sebelumnya belum menetapkan peraturan bagi anak dalam mengakses perangkat digital dan membiasakan anak menjalani peraturan dengan selalu menjalin komunikasi positif dua arah. Menurut para responden, komunikasi ini memegang peranan penting dalam memprediksi keberhasilan peraturan tersebut. Sedangkan kalau orang tua sudah menjalankan disiplin yang mengatur penggunaan perangkat digital oleh anak, maka ada kecenderungan intensitasnya berkurang karena selama WSFH orang tua banyak di rumah menemani anak. Selain itu, ide permainan beragam dan banyaknya teman sebaya yang dimiliki anak untuk melakukan permainan fisik juga menjadi indikator penurunan intensitas akses perangkat digital.

Alasan orang tua memberikan perangkat digital untuk anak yang dirangkum dalam penelitian ini adalah agar anak tidak mengganggu kegiatan orang tua, untuk menenangkan anak jika ia sedang bosan atau rewel, untuk membujuk agar anak mudah dimanipulasi untuk melakukan hal yang diinstruksikan orang tua, karena tidak ada kegiatan lain yang anak suka untuk melakukannya, dan agar anak dapat belajar melalui perangkat digital. selain itu, kecemasan berlebih akan penyebaran Covid-19 secara tidak langsung juga menjadi pertimbangan orang tua untuk menahan anaknya di dalam rumah yang pada akhirnya meningkatkan akses perangkat digital mereka. Hasil riset ini senada dengan temuan survey yang diungkapkan oleh Novianti \& Garzia (2020) bahwa 40\% responden memberikan gadget kepada anak agar ia tidak mengamuk, $22 \%$ beralasan agar anak lebih pintar, $21 \%$ agar anak tidak rewel dan sisanya atas alasan beragam.

Studi lain mengungkapkan bahwa $41 \%$ orang tua memberikan anak mereka tablet atau perangkat genggam untuk digunakan saat berada di restoran, dan $78 \%$ orang tua menyetujui penggunaan perangkat digital oleh anak-anak mereka (Nielsen, 2012; Wartella, Lauricella, Rideout, \& Connell, 2013). Survei nasional yang dilakukan oleh (CommonSenseMedia, 2011) di USA juga mengungkapkan bahwa sebanyak 38\% anak di bawah umur dua tahun telah menggunakan perangkat digital. Memang ada banya opini yang dikemukakan baik oleh para ahli, peneliti dan orang tua mengenai media, teknologi 
dan screen time (MeTS), baik yang mendukung atau tidak. Pada penelitian ini, peneliti bermaksud mengetahui seberapa besar intensitas penggunaan media, technology, and screen time (MeTS) oleh anak usia dini di masa wabah Covid-19, atas dasar alasan apa, untuk tujuan apa dan apa dampak yang diobservasi oleh orang tua selama interaksi anak dengan media, technology, and screen time (MeTS).

Ada konsensus umum di antara otoritas kesehatan bahwa screen time berlebihan membahayakan kesehatan anak usia dini dan berdampak buruk pada perkembangannya. American Academy of Pediatrics ( $A A P$ ) merekomendasikan agar anak di bawah usia 2 tahun tidak diperkenalkan dengan perangkat digital sedangkan anak berumur 2-5 tahun hanya diperbolehkan menghabiskan waktu kurang dari dua jam perhari dalam menggunakan perangkat digital (AmericanAcademyofPediatrics, 2013; Mulligan, Altmann, \& Brown, 2011). Departemen Kesehatan Australia memiliki kriteria yang lebih ketat. Mereka hanya merekomendasikan anak berumur 2-5 tahun untuk membatasi akses perangkat digitalnya kurang dari 1 jam per hari. Namun, data dikumpulkan dari International Children's Accelerometry Database antara 1997 hingga 2009 menunjukkan bahwa dua dari tiga anak tidak memenuhi pedoman screen time ini (Atkin, Sharp, Corder, \& van Sluijs, 2014).

Banyak orang tua yang tidak mengindahkan rekomendasi kesehatan ini. Alasannya, mereka percaya bahwa konten media bersifat mendidik. Salah satu survei menemukan $29 \%$ dari 1000 orang tua yang diwawancarai mengizinkan anak umur kurang dari 2 tahun untuk menonton televisi (TV) karena bagus untuk otak mereka (Zimmerman, Christakis, \& Meltzoff, 2007). Orang tua lain mengaku tidak membatasi screen time anak-anak untuk menghindari konflik dengan anak dan isolasi sosial yang mungkin dialami mereka. Selain itu orang tua juga beralasan untuk menghibur atau mengalihkan perhatian anak-anak (Evans, Jordan, \& Horner, 2011). Satu studi yang dilakukan untuk menghimpun pendapat ibu-ibu menyatakan bahwa mereka berkeyakinan menonton TV sangat ampuh untuk menenangkan anak sementara mereka mengerjakan pekerjaan rumah (Thompson et al., 2015). Studi lain mengungkapkan bahwa orang tua maupun pengasuh memberikan anak perangkat digital untuk mengkondisikan mereka ketika makan di restoran (Radesky et al., 2014).

\section{Untuk Belajar atau Hiburan?}

"Anak saya biasanya membuka youtube. Kalau ga chocomellon, ya baby bus Indonesia. Kalau dulu Upin Ipin, Omar Hana dan Nussa. Ganti-ganti kayaknya yang disukai anak", papar Ibu D ketika ditanyai mengenai hal yang diakses anak ketika memegang perangkat digital. "Selain itu ia juga mengakses aplikasi Marbel Hijaiyah Eduka Studio. Lebih sering itu deh kayaknya. Kan permainan. Selain itu saya juga berlangganan Shimajiro, ada videonya".

Ibu D menjelaskan bahwa pola penggunaan perangkat digital anaknya tergantung mood. Ada saat di mana anak merasa bosan dengan konten yang diaksesnya. Sebelumnya, anak Ibu D lebih sering mengakses perangkat digital untuk hiburan khususnya menonton video. Namun akhir-akhir ini ketika ia mengenal aplikasi belajar huruf hijaiyah yang dikemas dalam bentuk game, pola penggunaan perangkat digital anaknya lebih banyak ke kegiatan belajar. "Sekarang AL sudah bisa sampai huruf Qaf. Padahal baru empat hari."

Adapun Ibu At menyatakan bahwa kegiatan screentime anaknya lebih banyak untuk hiburan. "Mereka lebih banyak menolak jika dialihkan untuk kegiatan lain karena acara yang ditontonnya lebih menarik. Namun jika episode yang ditontonnya itu sudah pernah disiarkan, maka lebih mudah dialihkan. Karena mereka bosan. Biasanya main ular tangga atau monopoli."

Menurut Ibu H, aktivitas interaksi kedua anaknya dengan perangkat digital berimbang antara tujuan belajar dengan hiburan. "Ketika mereka mengakses academic kids atau youtube, mereka sambil belajar. Konten yang mereka akses hampir semua berbahasa inggris. Terlihat keahlian berbicara anak menggunakan bahasa inggris sangat berkembang." Perkembangan pesat kemampuan bahasa Inggris anak Ibu H terlihat ketika mereka menjalani rutinitas bertukar cerita di malam hari sebelum tidur. "Kami biasanya saling tanya jawab, tukar cerita dengan bahasa Inggris." 
Dari penuturan Ibu M yang diamini oleh Ibu S, ia selalu mengarahkan anaknya agar mengakses konten yang memiliki nilai edukasi. "Walaupun dikemas dalam bentuk hiburan seperti video atau game, kan tetap ada nilai pendidikannya," jelasnya. Adapun ketika ditanya mengenai pola penggunaan perangkat digital anaknya di rumah ayahnya, Ibu M mengaku tidak mengetahui secara pasti. "Kalau dahulu, saya yang sering mengatur penggunaan HP ini. Sekarang kalau sudah dikasih HP sendiri, kayaknya ya terserah anak saja mau mengakses apa. Buktinya anak saya banyak tahu aplikasi macam-macam."

Sedangkan Bapak L dan Ibu K dengan jelas menegaskan bahwa interaksi anaknya dengan perangkat digital hanya untuk hiburan. "Cuma youtube dan game." Ujarnya. Terkadang Ibu K menemani anaknya menonton video kalau tidak mempunyai kesibukan. Ia juga mengaku jarang mengalihkan anaknya saat menggunakan perangkat digital. "Anak saya sepertinya tidak kecanduan sih. Lebih sering main dengan teman. Di sini banyak anak-anak," jelas Ibu K.

Data-data yang dipaparkan para responden menyatakan bahwa secara garis besar anak mengakses perangkat digital untuk hiburan, namun konten-konten yang mereka akses memiliki nilai edukatif sehingga dapat mempromosikan peningkatan kognitif anak. Akuisisi nilai-nilai edukatif ini dapat dimaksimalkan jika orang tua menjalankan mediasi media dengan anaknya; mengkomunikasikan konten dengan anak dan meningkatkan kemampuan berpikir kritis melalui pertanyaan-pertanyaan.

Melalui observasi dari video yang dikirimkan untuk penelitian ini, peneliti melihat mayoritas anak menggunakan perangkat digital tersebut dalam keadaan sendirian. Penelitian lain melaporkan bahwa anak-anak dan remaja menghabiskan 7- 8 jam sehari menggunakan berbagai media termasuk televisi, video game, dan smartphone, lebih lama dari waktu yang mereka habiskan untuk aktivitas lain (V. Rideout, Foehr, \& ROberts, 2010). Anak usia dini sekarang cenderung bebas menggunakan perangkat digital, kapan saja dan di mana saja saat mereka menginginkannya. Penggunaan ini perlahan menjadi sebuah kerutinan sehingga interaksi sosialnya berkurang. Meskipun ada interaksi gaya baru melalui perangkat digital seperti video call dapat menumbuhkan hubungan elektronik, sosialisasi anak secara tatap muka tetap menjadi faktor inti yang mempengaruhi kompetensi sosialnya.

Belajar seringkali didasarkan pada hubungan sosial dan interaksi sosial. Bandura mengusulkan agar anak-anak belajar perilaku baru dengan mengamati orang lain sebagai model, kemudian menggunakan informasi ini sebagai panduan untuk bertindak dalam situasi yang akan dihadapinya kelak (Bandura, 1977). Demikian pula, Vygotsky percaya bahwa anak-anak hanya belajar fakta baru ketika mereka berinteraksi dengan orang-orang di lingkungan dan bekerja sama dengan rekan-rekan (Vygotsky, 1978) dalam apa yang ia gambarkan sebagai zona perkembangan proksimal. Ini merupakan penggambaran dari perbedaan tingkat keterampilan anak saat ini dengan tingkat keterampilan yang nantinya dapat ia capai dengan bimbingan orang dewasa atau teman sebaya yang lebih cakap. Dalam pandangan (Vygotsky, 1978), pergerakan ke pengetahuan baru tidak mungkin dicapai kecuali anak-anak mendapatkan pengaruh sosial untuk membantu proses belajar mereka. Situasi inilah yang dikenal dengan sebutan scaffolding.

Video dan game yang diakses anak melalui perangkat digital tidak jarang berisi konten kekerasan, karenanya cenderung berbahaya bagi perkembangan anak-anak. Banyak penelitian menunjukkan bahwa paparan konten kekerasan berulang, termasuk dari program televisi dan film, meningkatkan agresi dan rasa permusuhan anak-anak. (Ybarra et al., 2014) mengungkapkan hasil penelitian yang menunjukkan bahwa memainkan game berisi konten kekerasan dapat menyebabkan peningkatan agresivitas dan permusuhan, dan penurunan perilaku sosial. Selain itu, interaksi berulang ke media dengan konten kekerasan cenderung mengarah pada kecemasan dan ketakutan, pemikiran agresif, dan pemilihan kekerasan sebagai sarana utama untuk menyelesaikan konflik (Bushman \& Anderson, 2009). 


\section{Dampak Screen Time terhadap Aspek Perkembangan AUD}

Dunia saat ini jenuh dengan perangkat digital. Anak lahir dan berkembang dalam paparan media digital. Masa usia dini memegang peran penting dalam memprediksi perkembangan manusia dalam dunia digital ini, khususnya dalam dua aspek yang sering berhadap-hadapan; kognitif dan sosial. Paparan perangkat digital terhadap anak semakin meningkat. Karena itu, kekhawatiran tentang bagaimana perangkat digital ini mempengaruhi tumbuh kembang anak harusnya semakin diperhatikan oleh orang tua.

Ibu D mengakui bahwa perangkat digital dapat mengakselerasi kemampuan belajar anak karena kontennya yang interaktif dan disukai oleh mereka. Hal ini terbukti dengan kemampuan bahasa dan intrapersonal anaknya yang sangat lancar jika dibanding anak seumuran. Selain itu, bukti terbaru yang ditunjukkannya bahwa anaknya mampu mengenal huruf hijaiyah dengan cepat hanya dalam empat hari dengan belajar melalui aplikasi perangkat digital. Anaknya juga cepat bisa cebok sendiri karena stimulus dari video Shimajiro. "Kemampuan menyair (melantunkan syair maulid) juga mantap karena melihat video cucu Habib Syekh," tambah Ibu D. Namun hal positif ini hanya dapat terjaga jika orang tua menerapkan disiplin penggunaan perangkat digital yang sehat. "HP kan bisa merusak mata. Kalau sering main HP, perkembangan sosial anak terganggu." Suami Ibu D dalam masa tanggap darurat ini sering menemani anak mereka bermain setiap pagi dan sore. "Lebih banyak pagi sih, kadang sampai jam 10 jadi ia lupa jadwal main HP. Kalau sore saya yang menemani sepedaan atau main ke teman sebelah rumah." Selain menyebutkan dampak positif dari perangkat digital, Ibu D juga memaparkan dampak negatif seperti anak sering tidak menyahut jika dipanggil karena terlalu asyik menonton video.

Adapun Ibu At mengakui belum bisa melihat dampak positif dari screen time kedua anaknya. "Karena sepertinya hanya untuk hiburan." Namun ia mengakui, anaknya cepat terpengaruh oleh konten yang ditanyangkan. "Biasanya kalau nonton Ultraman, mereka berdua langsung aja beraksi. Malah sampai pukul-pukulan beneran."

Ibu $\mathrm{H}$ menyatakan bahwa banyak dampak positif dari interaksi anak dengan perangkat digital. Anak Ibu H yang masih duduk di TK A sudah lancar bercakap-cakap dengan bahasa Inggris. Selain itu secara kognitif mereka sudah mengenal bentuk, warna dan angka. Selain itu, tontonan tersebut memancing dialog saintifik dengan anak. Ini menunjukkan rasa ingin tahu yang besar. Anak Ibu $\mathrm{H}$ mampu mengkomunikasikan pikirannya berawal dari proses mengamati, mengumpulkan informasi dan menalar. "Sayangnya mereka kurang suka konten keagamaan seperti huruf hijaiyah, atau Nussa Rara," aku Ibu H. Dampak negatif yang dirasakan Ibu $\mathrm{H}$ adalah anak-anaknya sulit jika disuruh makan. Mereka mau makan jika sambil menonton Youtube. "Mereka jadi terlihat manja, tidak bisa makan sendiri, maunya disuapin terus." Selain itu, anak Ibu $\mathrm{H}$ juga terlihat pendiam di sekolah. Ada kendala adaptasi dan kendala bahasa. "Anak saya sangat pemalu. Justru setelah sekolah, kosa kata bahasa Banjarnya muncul". Selain itu ada kendala bawaan yang dialami anak Ibu H, yaitu masih cadel. Di umur yang ke 5 tahun lebih ini ia baru saja bisa mengucap g, $\mathrm{k}$ dan ng.

Adapun menurut Ibu M, dampak positif penggunaan smartphone oleh anaknya sangat terlihat di aspek kognitif. Anaknya menjadi lebih cerap mengenal bentuk, warna, huruf dan angka. Selain itu, Ibu M juga mengakui bahwa penggunaan smartphone membawa dampak negatif. Waktu di tempat abahnya, Alf selalu memegang smartphone. Jika smartphone itu diambil, Alf langsung mengamuk. Bahkan sampai memukul-mukulkan kepala. Selain itu, Alf juga menjadi malas belajar kecuali diimingi dengan smartphone. "Selama pandemi ini kan anak saya banyak dapat tugas dari bundanya di sekolah, namun ia tetap uring-uringan, malas belajar sendiri. Kalau diunduhkan aplikasi-aplikasi itu, ia jadi semangat belajarnya. Saya takutnya ini jadi keterusan pada hal lain. Bisa jadi nanti ia tidak mau disuruh apa-apa kecuali dikasih HP."

Dampak positif perangkat digital yang diasakan Ibu S pada perkembangan anaknya adalah pada aspek kognitif. "Anak hapal huruf, angka, hewan, buahan dan lagu-lagu anak." Namun dampak negatif yang terkait dengan akses perangkat digital ini adalah speech delay yang diderita anaknya. Ibu S juga sudah beberapa kali konsultasi ke psikolog. Dari observasi peneliti, lingkungan keluarga yang sepi menyebabkan stimulus yang diterima anaknya 
sedikit. Tidak banyak yang mengajak anak bicara. Selain itu, sosialisasi anak dengan lingkungan sekitar dan teman sebaya juga tidak banyak. Dari penuturan Ibu S, anaknya sering menonton video berbahasa Inggris yang mengakibatkan ia bingung ketika berbicara dengan anggota keluarga lain yang berbahasa Banjar.

Sedangkan Bapak L belum bisa mengamati nilai positif atau negatif yang dihasilkan selama anaknya berinteraksi dengan perangkat digital. "Rf belum bisa bicara, jadi saya kurang tahu apa dampaknya," ujar Bapak L. Namun yang terlihat jelas adalah anaknya sulit diajak makan kecuali sambil menonton video. Selain itu, anaknya sering berteriak atau menangis jika keinginannya tidak segera dipenuhi.

Orang tua melaporkan beberapa dampak positif dalam penggunaan perangkat digital yang kebanyakannya berada dalam domain perkembangan kognitif. Anak terlihat lebih cepat mengenal huruf, angka dan nama-nama benda melalui konten perangkat digital dan game yang diaksesnya. Selain itu, sebagian kecil juga melaporkan terdapat perkembangan seni yang menonjol pada anak karena menonton video syair maulid. Sedangkan dalam domain bahasa, beberapa anak mengalami perkembangan yang menggembirakan orang tua dengan syarat video-video itu tidak menggunakan bahasa beragam.

Memang perangkat digital menjadi alat yang efektif dalam mengasuh anak usia dini. Selain itu, berbagai riset juga menunjukkan bahwa penggunaan perangkat ini dapat mengakselerasi perkembangan kecerdasan anak, utamanya kognitif, bahasa dan seni, misalnya seperti yang dilaporkan oleh (Panjaitan, Yetti, \& Nurani, 2020) bahwa media digital animasi memberikan interaksi positif terhadap hasil belajar Agama Islam. (Taulany, 2020) juga menyatakan bahwa pembelajaran berbasis digital sudah selayaknya diterapkan pada AUD. Pendapat ini dikuatkan oleh hasil riset pengembangan aplikasi android tangram geometri Let's Be Healthy dapat meningkatkan rata-rata posttest kelompok eksperimen lebih signifikan dibanding kelompok kontrol. Selain itu, (Nasution, Hapidin, \& Fridani, 2020) melalui risetnya juga menunjukkan bahwa penggunaan ICT dan minat belajar mempengaruhi kesiapan membaca AUD.

Ada implikasi penting yang dirasakan pada konsep belajar anak dengan meluasnya penggunaan perangkat digital oleh mereka. Anak pada zaman ini memiliki konsep komunikasi dan kreatifitas berbeda, dan perangkat digital mempunyai saham yang besar dalam mengkonstruksi perbedaan cara pandang tersebut (Parette \& Blum, 2016; Wartella, Kirkpatrick, Rideout, Lauricella, \& Connell, 2014; Wartella et al., 2013). Studi mengungkapkan bahwa anak-anak umur dua tahun secara alami akan berinteraksi dengan layar sentuh dengan cara yang sama mereka menggunakan naluri alami untuk bermain dengan mainan baru. Selain itu, setelah keterlibatan bersama dan eksplorasi terbimbing oleh pengasuh, hasil menunjukkan bahwa anak-anak menjadi lebih terlibat dalam mendapatkan pemahaman baru melalui pemanfaatan tablet (Geist, 2012). Dalam domain pengembangan keaksaraan, guru PAUD juga menyatakan bahwa usaha mengintegrasikan komputer dalam pengajaran mereka memiliki hasil positif untuk meningkatkan literasi anak (Al-barakat \& Bataineh, 2008; Ihmeideh, 2010).

Dampak negatif perangkat digital dapat diminimalisir dengan penerapan disiplin yang sehat. Disiplin ini terlebih dahulu harus dikomunikasikan dengan anak agar mereka memiliki rasa tanggung jawab terhadap pelaksanaan disiplin tersebut. Keputusan penetapan disiplin yang sepihak cenderung mendapat perlawanan dari anak. Dalam penelitian ini, dampak negatif yang ditekankan orang tua seiring meningkatnya intensitas penggunaan perangkat digital oleh anak berada dalam domain perkembangan sosial, emosional dan moral. Anak terlihat terlalu fokus setiap menggunakan perangkat digital sehingga tidak menyahut panggilan orang tua, menolak bermain bersama teman, marah jika diganggu saat menggunakan perangkat digital, menangis jika tidak dipenuhi keinginan untuk menggunakan perangkat digital dan menunjukkan egosentris yang tinggi ketika menggunakannya. 
Stimulus yang diberikan oleh perangkat digital mendorong rasa keingintahuan anak secara konsisten yang pada gilirannya tidak sedikit berakhir pada kecanduan. Anak usia dini terpapar konten media melalui beberapa perangkat sekaligus, utamanya perangkat digital dan televisi, di berbagai lokasi dan dalam berbagai format. Serbuan perangkat digital ini tidak dapat dipungkiri berpotensi mengarah ke perkembangan yang dipenuhi kebingungan. Perkembangan sporadis penggunaan media, yang awalnya hanya sebuah televisi di ruang keluarga, menggeser mindset dan perilaku anak. Mereka menjadi terbiasa bermain dengan perangkat digital ketika perkumpulan keluarga, ketika berada di ruang kerja orang tuanya, ketika ikut mengendarai alat transportasi bahkan ketika makan sekalipun. Kehadiran smartpohe menciptakan dunia baru yang mereduksi nilai-nilai yang selama ini dipercayai sebagai nilai luhur dan dipertahankan dalam lintas generasi.

Perangkat digital dapat dikatakan merebut pengamalan sosial anak untuk berinteraksi dengan orang lain dan alam sekitarnya. (Hosokawa \& Katsura, 2018) dalam penelitiannya menemukan penggunaan perangkat digital oleh AUD terkait dengan kemungkinan masalah perilaku yang lebih tinggi (melakukan masalah, hiperaktif dan kesulitan membagi perhatian).

Adapun dampak negatif yang terlihat pada aspek perkembangan bahasa adalah kebingungan bahasa karena video yang diakses menggunakan bahasa berbeda dari yang dituturkan orang sekitarnya, utamanya bahasa inggris dan melayu. Selain itu, speech delay juga dikaitkan dengan kebiasaan anak menonton video ini. Hasil penelitian ini senada dengan penelitian (Chonchaiya \& Pruksananonda, 2008) bahwa paparan televisi terhadap anak lebih dari 2 jam sehari, walaupun tidak secara langsung, berhubungan secara signifikan pada keterlambatan bahasa. Penelitian lain juga mengkonfirmasi bahwa perangkat digital secara negatif mempengaruhi penggunaan dan akuisisi bahasa, perhatian, kognitif dan fungsi eksekutif -kemampuan mengingat suatu informasi dan menggunakannya kembalianak di bawah 5 tahun; (Courage \& Howe, 2010; Courage \& Setliff, 2010; Lapierre \& Taylor, 2012; Lillard, Li, \& Boguszewski, 2015).

Beberapa penelitian memperingatkan bahwa anak-anak yang memiliki akses tinggi terhadap media, technology, and screen time (MeTS) dapat menyebabkan penurunan fungsi eksekutif, kinerja akademik, interaksi sosial yang berkualitas dengan orang tua dan teman sebaya, dan bermain kreatif. Selain itu, media, technology, and screen time (MeTS) berlebihan tanpa aturan dapat meningkatkan obesitas, perilaku agresif, kasar, intimidasi, desensitisasi terhadap kekerasan, kurangnya empati kepada korban, ketakutan, depresi, mimpi buruk dan gangguan tidur (Weibel, 1992) (American Academy of Pediatrics., 2011; Campaign for a Commercial-Free Childhood \& Alliance for Childhood, 2012; Lillard \& Peterson, 2011).

Ada ulasan literature menarik mengenai akuisisi keterampilan anak-anak dengan teknologi. Studi ini berfokus pada konstruksi makna dan pembagian pemahaman melalui konten media seperti video YouTube. Para peneliti menyatakan bahwa keterlibatan anak usia dini dengan perangkat digital tidak boleh pasif. Pengalaman media, technology, and screen time (MeTS) harus melibatkan diskusi dan interaksi dengan orang lain seperti orang tua, teman sebaya, dan guru. Diskusi interaktif dengan anak usia dini ketika mereka mengakses perangkat digital dapat menjadi predictor kuat untuk hasil yang positif (Couse \& Chen, 2010; Davidson, Given, Danby, \& Thorpe, 2014). Fokus tentang komunikasi yang dijalankan orang tua dengan anak saat mempergunakan perangkat digital ini akan digarap oleh peneliti pada penelitian selanjutnya.

\section{SIMPULAN}

Selama masa pandemi Covid-19, terjadi peningkatan akses perangkat digital pada anak. Belum adanya disiplin yang diterapkan orang tua dalam mengatur penggunaan perangkat digital, minimnya ide permainan yang dimiliki orang tua dan sedikitnya teman sebaya menjadi pemicunya. Faktor yang mempengaruhi pola, intensitas dan jangka waktu anak usia dini dalam menggunakan perangkat digital adalah jumlah kesibukan orang tua, 
perilaku penggunaan perangkat digital oleh orang tua, jumlah saudara, pengetahuan orang tua tentang dampak penggunaan perangkat digital, kondisi lingkungan tempat anak tumbuh, dan dukungan pengasuhan dari pihak lain. Perangkat digital memberikan efek positif pada perkembangan kognitif, namun berdampak negatif pada perkembangan sosial emosional anak.

\section{DAFTAR PUSTAKA}

Al-barakat, A. A., \& Bataineh, R. F. (2008). Jordanian student teachers' use of computers to develop primary stage pupils ' literacy skills. 4(4), 64-87.

American Academy of Pediatrics. (2011). Media use by children younger than 2 years. Pediatrics, 128(5), 1-6. https:// doi.org/10.1542

AmericanAcademyofPediatrics. (2013). Policy statement: Children, adolescents, and the media. Pediatrics.

Atkin, A. ., Sharp, S. ., Corder, K., \& van Sluijs, E. (2014). International Children's Accelerometry Database (ICAD) Collaborators. Prevalence and correlates of screen time in youth: An international perspective. Am. J. Prev. Med., 47, 803.

Bandura, A. (1977). Social learning theory. Englewood Cliff NJ: Prentice Hall.

Bushman, B. J., \& Anderson, C. A. (2009). Comfortably numb: Desensitizing effects of violent media on helping others. Psychological Science, 20(3), 273-277. https:// doi.org/10.1111/j.1467-9280.2009.02287.x

Campaign for a Commercial-Free Childhood \& Alliance for Childhood. (2012). Facing the screen dilemma: Young children, technology and early education. Boston, MA: Campaign for a Commercial-Free Childhood.

Chiong, C., \& Shuler, C. (2010). Learning: is there an app for that? Investigations of young children's usage and learning with mobile devices and apps. New York: The Joan Ganz Cooney Center Sesame Workshop.

Chonchaiya, W., \& Pruksananonda, C. (2008). Television viewing associates with delayed language development. 977-982. https:// doi.org/10.1111/j.1651-2227.2008.00831.x

Cingel, D. P., \& Krcmar, M. (2013). Predicting Media Use in Very Young Children: The Role of Demographics and Parent Attitudes. Communication Studies, 64(4), 374-394. https:/ / doi.org/10.1080/10510974.2013.770408

CommonSenseMedia. (2011). Zero to eight: Children's media use in America.

CommonSenseMedia. (2013). Zero to eight: Children's media use in America 2013. San Francisco: Common Sense Media.

Courage, M. L., \& Howe, M. L. (2010). To watch or not to watch : Infants and toddlers in a brave new electronic world. Developmental Review, 30(2), 101-115. https:// doi.org/10.1016/j.dr.2010.03.002

Courage, M. L., \& Setliff, A. E. (2010). When babies watch television: Attention-getting , attention -holding, and the implications for learning from video material. Developmental Review, 30(2), 220-238. https:// doi.org/10.1016/j.dr.2010.03.003

Couse, L. J., \& Chen, D. W. (2010). A tablet computer for young children? Exploring its viability for early childhood education. Journal of Research on Technology in Education, 43(1), 75-98. https:// doi.org/10.1080/15391523.2010.10782562

Cristia, A., \& Seidl, A. (2015). Parental Reports on Touch Screen Use in Early Childhood. PLoS ONE, 10(6), 1-20. https://doi.org/10.1371/journal.pone.0128338

Davidson, C., Given, L. M., Danby, S., \& Thorpe, K. (2014). Talk about a YouTube video in preschool: The mutual production of shared understanding for learning with digital technology. Australasian Journal of Early Childhood, 39(3), 76-83. https:// doi.org/10.1177/183693911403900310

Evans, C. A., Jordan, A. B., \& Horner, J. (2011). Only Two Hours? A Qualitative Study of the Challenges Parents Perceive in Restricting Child Television Time. Journal of Family Issues, 32(9), 1223-1244. https:/ / doi.org/10.1177/0192513X11400558 
Geist, E. G. (2012). A qualitative examination of two year-olds interaction with tablet based interactive technology. Journal of Instructional Psychology, 39(1), 26-35.

Hosokawa, R., \& Katsura, T. (2018). Association between mobile technology use and child adjustment in early elementary school age. PLoS ONE, 13(7), 1-17.

Huston, A. C., Wright, J. C., Marquis, J., \& Green, S. B. (1999). How young children spend their time: Television and other activities. Developmental Psychology, 35(4), 912-925. https:// doi.org/10.1037/0012-1649.35.4.912

Ihmeideh, F. (2010). The role of computer technology in teaching reading and writing: Preschool teachers' beliefs and practices. Journal of Research in Childhood Education, 24(1), 60-79. https://doi.org/10.1080/02568540903439409.

Lapierre, A. M. A., \& Taylor, J. (2012). Background Television in the Homes of US Children. Pediatrics, 130(5), 1-8. https:/ / doi.org/10.1542/ peds.2011-2581

LeBlanc, A. G., Spence, J. C., Carson, V., Gorber, C., S., D., S., J., ... Tremblay, M. S. (2012). Systematic review of sedentary behaviour and health indicators in the early years (aged 0-4 years). Applied Physiology, Nutrition, and Metabolism, 37, 753-772.

Lillard, A. S., Li, H., \& Boguszewski, K. (2015). Television and Children' s Executive Function. Advances in Child Development and Behavior, 48, 219-248.

Lillard, A. S., \& Peterson, J. (2011). The immediate impact of different types of television on young children's executive function. Pediatrics, 128(4), 644-649. https://doi.org/10.1542/peds.2010-1919

Mulligan, D. ., Altmann, T. ., \& Brown, A. (2011). Media use by children younger than 2 years. Pediatrics.

nasional.kompas.com. (2020). jokowi-saatnya-kerja-dari-rumah-belajar-dari-rumah-ibadahdi-rumah.

Nasution, R. H., Hapidin, \& Fridani, L. (2020). Pengaruh Pembelajaran ICT dan Minat Belajar terhadap Kesiapan Membaca Anak Usia Dini. Jurnal Obsesi : Jurnal Pendidikan Anak Usia Dini, 4(2), 733-746. https:// doi.org/10.31004/obsesi.v4i1.326

Nielsen. (2012). American families see tablets as playmate, teacher and babysitter.

Novianti, R., \& Garzia, M. (2020). Penggunaan Gadget pada Anak; Tantangan Baru Orang Tua Milenial. Jurnal Obsesi: Jurnal Pendidikan Anak Usia Dini, 4(2), 1000. https://doi.org/10.31004/obsesi.v4i2.490

Panjaitan, N. Q., Yetti, E., \& Nurani, Y. (2020). Jurnal Obsesi : Jurnal Pendidikan Anak Usia Dini Pengaruh Media Pembelajaran Digital Animasi dan Kepercayaan Diri terhadap Hasil Belajar Pendidikan Agama Islam Anak Abstrak. Obsesi : Jurnal Pendidikan Anak Usia Dini, 4(2), 588-596. https:// doi.org/10.31004/obsesi.v4i2.404

Parette, H. P., \& Blum, C. (2016). Using e $l$ ar t $i$ c i pat $i$ o $n$ b i Flex in Technology-Supported, Universally Designed Preschool Activities.

pusdiklat.kemdikbud.go.id. (2020). surat-edaran-mendikbud-no-4-tahun-2020-tentangpelaksanaan-kebijakan-pendidikan-dalam-masa-darurat-penyebaran-corona-virusdisease-covid-1-9.

Radesky, J. S., Kistin, C. J., Zuckerman, B., Nitzberg, K., Gross, J., Kaplan-Sanoff, M., ... Silverstein, M. (2014). Patterns of mobile device use by caregivers and children during meals in fast food restaurants. Pediatrics, 133(4), 843-849. https://doi.org/10.1542/peds.2013-3703

Rideout, V., Foehr, U. ., \& ROberts, D. . (2010). Generation M2: Media in the lives of 8- to 18year-olds. Menlo Park, CA: Kaiser Family Foundation.

Rideout, V. J. (2013). Zero to Eight: Children's Media Use in America 2013. San Francisco, CA: Common Sense Media.

Taulany, H. (2020). Media Tangram Geometri “Let's Be Healthy” Berbasis Android untuk Meningkatkan Kemampuan Berpikir Geometri Anak Usia Dini. Jurnal Obsesi : Jurnal Pendidikan Anak Usia Dini, 4(1), 1-10. https://doi.org/10.31004/obsesi.v4i2.365

Thompson, D. A., Polk, S., Cheah, C. S. L., Vandewater, E. A., Johnson, S. L., Chrismer, M. C., 
DOI: $10.31004 /$ obsesi.v5i1.544

\& Tschann, J. M. (2015). Maternal Beliefs and Parenting Practices Regarding Their Preschool Child's Television Viewing: An Exploration in a Sample of Low-Income Mexican-Origin Mothers. Clinical Pediatrics, 54(9), 862-870. https:/ / doi.org/10.1177/0009922815574074

Tremblay, M. S., LeBlanc, A. G., Kho, M. E., Saunders, T. J., Larouche, R., Colley, R. C., ... Connor Gorber, S. (2011). Systematic review of sedentary behaviour and health indicators in school-aged children and youth. International Journal of Behavioral Nutrition and Physical Activity, 8, 98.

Vygotsky, L. (1978). Interaction between learning and development. New York: W.H. Freeman and Company.

Wartella, E., Kirkpatrick, E., Rideout, V., Lauricella, A., \& Connell, S. (2014). Revised media, technology, and reading in Hispanic families: A national survey.

Wartella, E., Lauricella, A. ., Rideout, V. J., \& Connell, S. (2013). PARENTING IN THE AGE OF DIGITAL TECHNOLOGY. Northwestern.

Weibel. (1992). The Library As Literacy Classroom: A Program For Teaching. Chicago: American Library Association.

Ybarra, M. L., Diener-west, M., Markow, D., Leaf, P. J., Hamburger, M., \& Boxer, P. (2014). Linkages Between Internet and Other Media Violence With Seriously Violent Behavior by Youth. 122(5). https://doi.org/10.1542/peds.2007-3377

Zimmerman, F. J., Christakis, D. A., \& Meltzoff, A. N. (2007). Television and DVD/Video Viewing in Children Younger Than 2 Years. Arch. Pediatr. Adolesc. Med, 161(May), 473-479. https://doi.org/10.1177/0192513X11400558 